\title{
Influence of climate conditions on tax revenues
}

\author{
Mihai Mutascu ${ }^{1,2}$
}

\begin{abstract}
In this paper, we investigate the effects of climate conditions on collected tax revenues, based on a panel-model approach. The dataset includes 123 countries and covers the period 1996-2010. The main results demonstrate that climate has a significant impact on tax revenues, the assumed function being nonlinear, with a cubic $\cap$ and incomplete $U$-shape. We also find that governments situated in temperate climate zones, with low to moderate temperatures (the 'optimal temperature' in our investigation), can ensure a good collection of tax revenues. The study suggests that a significant increase in collected tax revenues, without a major negative reaction by taxpayers, can be easily obtained by the public authority if situated in a temperate climate zone, that is, one with moderate temperatures.
\end{abstract}

KEY WORDS: $\quad$ climate conditions; tax revenues; effects; tax policy

JEL Classification: Q54; H20; C23

${ }^{1}$ West University of Timisoara, Romania; ' ${ }^{L} \mathrm{EO}$ (Laboratoire d'Economie d'Orléans), France

\section{Introduction}

A modern government collects taxes and allocates them to fulfill its main constitutional goals, under an extended set of determinants, the climate being ignored for a long period of time. Classical determinants of taxation are ordered by I. Lago-Peñas and S. Lago-Peñas (2008) in four categories: socio-demographic characteristics (gender, age, marital status, education, employment status, religiosity and social class); political and social attitudes (trust in courts, the legal system, trust in politicians, democracy level, national pride, social capital, the perception of cor-

Correspondence concerning this article should be addressed to: Mihai Mutascu, Faculty of Economics and Business Administration West University of Timisoara 16, H. Pestalozzi St. 300115 , Timisoara, Romania Tel: +40 256 592505, Fax: +40 256592500. E-mail: mihai.mutascu@gmail.com ruption and voting behavior); fiscal parameters (tax rates, fine rate, audit probability, risk aversion and personal income); and contextual determinants (extent of direct democracy, language fragmentation and existence of regional cleavages).

It is easy to see that the mentioned categories do not take any geographical feature types into account. As Nordhaus (2006) demonstrates, if the connections between economic phenomena or processes and geography is generally evident for nearly all persons, modern macroeconomics ignores this linkage. Determinants, such as climate conditions, water proxy, soils, pests and permafrost are practically ignored. According to the same author, there are two types of geophysical factors that can be used in economics studies: nonstochastic factors on the relevant time scale (latitude, distance from coastlines or elevation) and stochastic factors with slowly moving means and variability (climate conditions or soils). 
Rehdanz and Maddison (2005) state that the climate also has a great impact on human behavior; even so, this type of approach was preferred during the later $19^{\text {th }}$ and much of the early $20^{\text {th }}$ century but has been rejected by geographers since the 1960s and 1970s. The mentioned authors consider that the climate influence on humans is related to 'societal (e.g., civilization, culture and migration), psychological (e.g., aggression, cognition and mental illness), physiological (e.g., health, allergies, diet and nutrition), economic (e.g., energy production, tourism and agriculture) and ecological conditions (e.g., fauna and flora)'.

The connection 'tax revenues-climate' has two principal transmission channels: a direct one and an indirect one. The direct channel implies that the level of collected tax revenues depends on citizens' behavior, which differs from one climate zone to another. The climate influence on human behavior is sustained by many recent studies (e.g., Anderson, 2001; Berkowitz, 1993 or Boyanowsky, 1999). The authors find that heat is associated with high degrees of aggressiveness and other complex behavioral changes. In an extended view, McDougall (2005) argues that persons situated in the cool climate zones are characterized by honesty, pragmatism, and also great independence of character, individual initiative, and tenacity of will. As tax compliance is a dimension of human behavior, the climate can play an important role in the level of collected tax revenues through the intensity of tax compliance. The indirect channel consists of the impact of climate conditions on tax revenues through a set of socio-economic determinants. In this case, GDP growth, and thus tax base growth, under climate conditions determines a positive impact on tax revenues. At the same time, the structure of the economy and economic openness can also play an important role for extension of the tax base under a considered climate environment.

The aim of this paper is to analyze the effects of climate conditions on collected tax revenues, based on a panelmodel approach. The data set includes 123 countries and covers the period 1996-2010. The main results show that the climate has a significant impact on tax revenues, the assumed function being nonlinear, with a cubic $\cap$ and $U$-shape. We also find that governments situated in temperate climate zones, with moderate temperatures (the 'optimal temperature' in our investigation), can ensure a good collection of tax revenues.
Regarding tax revenues under influence of climate conditions, the literature in the field is practically absent. Some results are obtained, but the analyses are focused on the climates' impact on economic growth, economic development, revenue inequality, poverty, institutional quality or agricultural and industrial output. The pioneers in the study of this topic are the illustrious Montesquieu (1750) and Smith (1776), cufollowed in the contemporary period by many other researchers (e.g. Acemoglu, Johnson \& Robinson, 2002; Bansal \& Ochoa, 2012; Bloom \& Sachs, 1998; Dell, Jones \& Olken, 2012; Gallup \& Sachs, 1999; Gallup, Sachs \& Mellinger, 1999; Hall \& Jones, 1999; Mellinger, Sachs \& Gallup, 1999; Rodrik, Subramanian \& Trebbi, 2004; Sachs \& Warner, 1997; Sylwester, 2004).

In the contemporary period, Sachs and Warner (1997) investigated the growth in 23 African countries, for the period 1965-1990, based on a cross-country regression model. The results demonstrate that poor economic policies determine slow economic growth, without any openness to international markets. Furthermore, the authors add new determinants of slow growth, i.e., lack of access to the sea and tropical climate conditions. One year later, Bloom and Sachs (1998) explored the influence of climatic conditions on some economic variables and emphasized that poorer zones are correlated with tropical climates, as a result of tropical ecology effects on human health and agricultural productivity. The temperate climate is associated with the rich zones.

Dell, et al. (2012) change the type of climate with temperature in their investigations. The authors study the effect of temperature's fluctuations on economic activity, with a sample of 125 countries. The main conclusion shows that higher temperatures substantially reduce economic growth in poor countries. In parallel, they associate higher temperatures with reduced agricultural output, industrial output and political stability. More recently, Bansal and Ochoa (2012) investigated the connection between temperature, aggregate risk and expected returns, utilizing a sample of 38 countries in the period 1960-2008. The researchers note that temperature represents an aggregate risk factor of economic growth. In this respect, countries closer to the Equator reveal a positive temperature risk premium that decreases as one moves farther away from the Equator. 
New evidence concerning the 'climate - economy' nexus was revealed by Gallup and Sachs (1999). They focus on food production and find a strong correlation between food production and climate zone type. Because of certain inputs, such as capital, labor and fertilizers, harvests are much lower in tropical zones, compared with temperate zones, which experience greater harvests.

Mellinger, et al. (1999) are more analytical, examining the connection between climate (eco zones), water navigability and economic development (GDP per capita) in each of 152 countries, with a population of 1 million or more, in 1995. They emphasize that GDP per capita and density of economic activity (in GDP per $\mathrm{km}^{2}$ ) are high in temperate zones and in areas accessible to the sea (within $100 \mathrm{~km}$ of the ocean or a seanavigable waterway).

Hall and Jones (1999) choose a new topic: the impact of climate on revenue inequality. The authors focus on the issues of per capita income discrepancy across nations and illustrate a strong correlation between geography (measured as the distance from the equator) and per capita output by country. The location affects economic success because the position of human settlements can influence institutions. On the same topic, Gallup, et al. (1999) analyze the effects of location and climate on income levels and income growth. Novel is that a set of control variables is used, such as transport costs, disease burdens and agricultural productivity, among other channels. The main conclusion stresses that geography also affects economic policy choices.

Other authors link temperature, as an independent variable, with some national characteristics, such as institutional quality (e.g., Acemoglu, et al., 2002; Rodrik, et al., 2004). The results of Rodrik, et al. (2004) reveal that the institutions, geography and trade are the most important determinants of income levels around the world. Moreover, geography is considered to have weak direct effects on income levels. Sylwester (2004) juxtaposes history with geography as the important stimulus pair of institutions and income. Utilizing a cross-section of countries approach, he suggests that only being landlocked has a strong influence on revenue inequality.

In the present paper, we extend the literature in the field by focusing on the climate implications in the economy and find new evidence regarding the determinants of collected tax revenues. As there are cyclical climate changes, this contribution could help governments to adjust their tax policy taking into account this climate periodicity.

The rest of the paper is structured as follows: Section 2 highlights the methodology and data. Section 3 contains the results. Section 4 presents our conclusions.

\section{Methodology and data}

The influence of climate on tax revenues is explored based on a large sample, determined by 123 crosssections (123 countries), from 1996 to 2010 (Table 1, in the Appendix), using a panel-model approach. Two variables are considered for investigating this nexus: the tax revenues per capita, as a dependent variable, and the climate, as an independent interest variable. The dependent variable is represented by tax revenues per capita $(\tau)$ and reveals the level of tax revenues collected by general government per person in U.S. dollars.

The interest determinant is climate $(\delta)$. Climate zones are characterized by four coordinates: annual mean daily temperature, total annual precipitation, total annual potential evapo-transpiration (PET), and elevation. As the temperature is a very good proxy for climate, this coordinate is selected to capture weather conditions. Temperature measures annual mean daily temperature degrees, on the Fahrenheit scale, and quantitatively denotes the common notions of hot and cold.

The main hypothesis of this analysis is that climate conditions determine the level of government tax receipts. The function has this shape (the variables are treated as elastic):

$\ln \tau=f(\ln \delta)$,

where $\tau$ equals the amount of tax revenues per capita in U.S. dollars, and $\delta$ equals the climate variable (the temperature). The scatter diagram of this function, presented in Figure 1, is performed using the nonparametric Nearest Neighbor Fit method (degree $=3$; $\operatorname{span}=0.9$ ).

The scatter plot with Nearest Neighbor Fit method suggests that the association between the two variables is not linear, having a cubic $\bigcap$ and incomplete $U$-shape. 


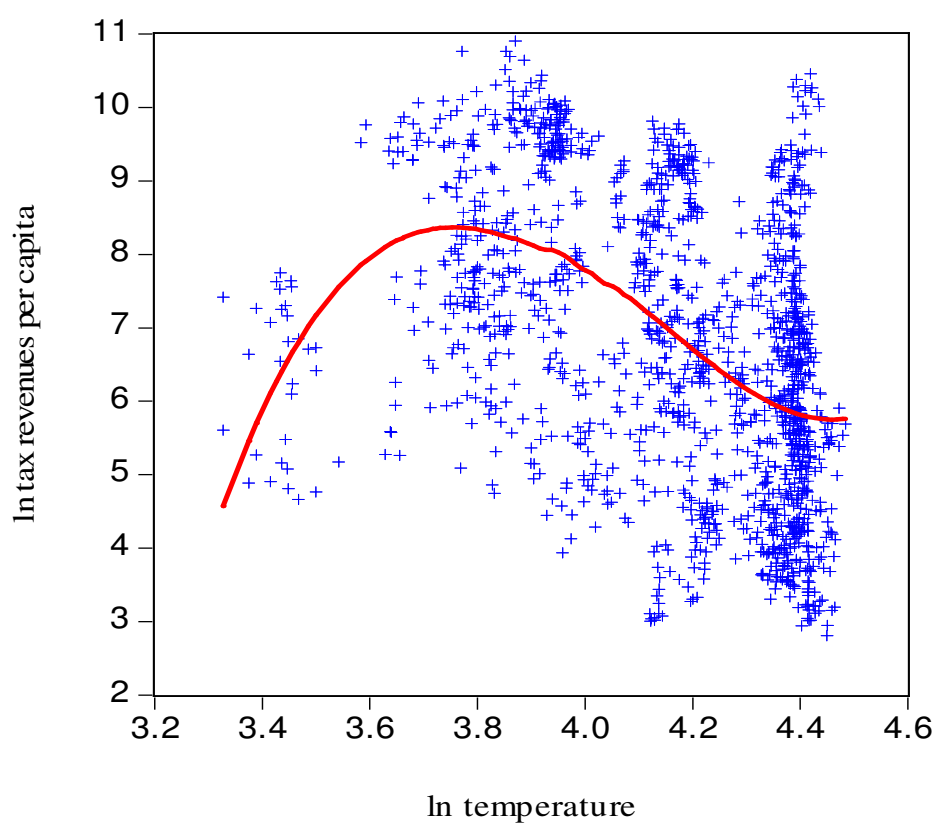

Figure 1. The relationship between In tax revenues per capita and In temperature

The Ramsey's Reset Test, assuming cubic and square functions, is performed to reinforce the nonlinear relationship between the $\ln$ tax revenues per capita and ln temperature. Additional tests are employed to verify the existence of polynomial degree greater than 3 .

The robustness of these simple stylized facts is explored using several econometric techniques. The extended OLS naïve panel-model is as follows:

$\ln \left(\tau_{i t}\right)=\alpha+\beta_{0} \ln \left(\delta_{i t}\right)+\beta_{1} \ln \left(\delta_{i t}\right)^{2}+\beta_{2} \ln \left(\delta_{i t}\right)^{3}+\varepsilon_{i t}$,

where $\alpha$ is the intercept, $\beta_{0,1,2}$ are the slopes of the interest variables, $i$ is the country, $t$ is the time and remainder, and $\varepsilon_{i t}$ is the error term, which varies over both country, and time.

To isolate the effect of interest determinants, we enter three categories of control variables: one inspired by the appropriate tax literature, one derived from macroeconomic policy, and another one represented by robustness variables. Based on this adjustment, the extended linear model becomes:

$\ln \left(\tau_{i t}\right)=\alpha+\beta_{0} \ln \left(\delta_{i t}\right)+\beta_{1} \ln \left(\delta_{i t}\right)^{2}+\beta_{2} \ln \left(\delta_{i t}\right)^{3}+\sum_{k=1}^{n} \beta_{k} X_{k, i t}+\varepsilon_{i t}$

where $\beta_{k}$ is the coefficient of control independent variable $k$ by $n$ type, and $X$ is the control independent variables.

The first group of control variables includes determinants inspired from the tax literature, such as the gross domestic product (GDP), the size of the industrial sector and the size of the agricultural sector. The GDP reveals the level of the GDP in US dollars and captures the size of the economy. It is expected the GDP have a strong positive impact on tax revenues (e.g., Katircioglu, 2010; Tosun \& Abizadeh, 2005). The last two variables, the size of the industrial sector and the size of the agricultural sector, measure the value added by the industrial/agricultural sector as percentages of GDP. There are many studies that explain these 
variables' significant effects on collected tax revenues (e.g., Agbeyegbe, Stotsky and WoldeMariam, 2006). As the agricultural sector is difficult to tax, many studies find a negative connection between tax revenues and the size of the agricultural sector. On the contrary, growth in the industrial sector might be expected to have a positive impact on taxes.

The second group of control determinants captures macroeconomic policy variables and includes the inflation rate, the balance of trade, government debt, government final consumption expenditures and net foreign direct investment (FDI). The inflation rate is the rate of change in the consumer price level. Excellent contributions regarding the inflation - tax nexus are provided by Olivera (1967) and Tanzi (1977). Many conclusions state that inflation has a negative influence on tax revenues. The balance of trade measures the difference between the monetary value of exports and imports of an economy as a percentage of GDP. According to Agbeyegbe, et al. (2006), a positive balance of trade has a positive impact on tax revenues. The third control variable is represented by government debt, which shows the general government gross debt as a percentage of GDP. Battaglini and Coate (2008) find a strong positive correlation between public debt and tax revenues. The fourth variable, government final consumption expenditures, quantifies the government final consumption expenditure as a percentage of GDP and also has a significant positive influence on tax revenues, as Taha and Loganathan (2008) note. The last control determinant by macroeconomic policy origins is the net FDI. It captures the difference between inward foreign direct investment and outward foreign direct investment as a percentage of GDP. Notable research regarding the implications of net FDI on tax revenues was conducted by Huizinga and Nielsen (1997; 2002), Huizinga and Nicodème (2006), Mintz (1994), Richter and Wellisch (1996), Wildasin and Wilson (1998), Wildasin (2003). They conclude that the variables are all concurrently either positive or negative.

The last group of control variables is for robustness and contains freedom from corruption, literacy index and political stability. Freedom from corruption reveals the corruption intensity (the score 100 means low corruption, while a level of 0 indicates a very corrupt government). The main outputs of Ghura (1998);
Friedman, et al. (2000); Fjeldstad and Tungodden (2003), and Imam and Jacobs (2007) demonstrate that corruption is negatively correlated with tax revenues. The literacy index is the third control variable for robustness and indicates how many adults can read and write in a certain area or nation, as a percentage of the total adult population. According to Kenney and Winer (2001), and Mahadavi (2008), this determinant is positively correlated with collected tax revenues. Finally, political stability is captured by the regime durability and reveals, according to Marshall, Jaggers and Gurr (2011), the number of years since the most recent regime change or the end of the transition period defined by a lack of stable political institutions. The level 0 indicates the first year during which a new (post-change) polity is established. New investigations regarding the relationship between political stability and tax revenues belong to Estrada, Mutascu and Tiwari (2013) and reveal ambiguous outputs.

Table 2 in the Appendix demonstrates descriptive statistics of utilized variables, while Table 3 presents the sources of data. Tax revenues, temperature, GDP and freedom from corruption have logarithm forms and are treated as elastic, except for the variables with non-strict positive values and the variables already expressed as percentages.

Several explanatory variables can be suspected for endogeneity, especially the government determinants and the variables directly affected by fiscal policy, such as GDP, inflation, general gross debt, government consumption and net FDI. To deal with this possible endogeneity issue and to control for the bias due to the utilization of lagged dependent variables, a generalized method of moments (GMM) approach is followed. The first popular GMM approach was conducted by Arellano and Bond (1991). Unfortunately, their dynamic GMM estimator can lead to weak estimations, as the lagged level of the regressors are poor instruments for the first-differenced regressors. An augmented GMM version was developed by Blundell and Bond (1998), called the GMM-system. This last proposal utilizes the levels of variables, as in equation (2), for obtaining a system of two equations: one differenced and one in levels. The GMM-system estimations performed follow robust specifications and include time dummy variables to remove errors from the universal timerelated shocks, as Roodman (2009 a,b) notes. For all 
GMM estimators, the Sargan test and Hansen J-test are employed to check the validity of the considered instruments, while the tests for $\mathrm{AR}(1)$ and $\mathrm{AR}(2)$ processes in first differences are performed to detect the presence of autocorrelations.

The most employed instruments are the lags of endogenous variables, including the time dummy variables. A climatic dummy variable is also selected as an additional instrument. This variable represents a good proxy for GDP, according to Mellinger, et al. (1999). The climate dummy is 1 if the climate is warm or tropical and 0 if the climate is cool, polar or boreal. The binary values of dummy variable are fixed according to the International Panel on Climate Change (2006) climate zone types (Figure 2, in Appendix). The International Panel on Climate Change (IPCC) was established by the United Nations Environment Programme (UNEP) and the World Meteorological Organization (WMO) to provide the world with a clear scientific view on the current state of knowledge in climate change and its potential environmental and socio-economic impacts.

The next section illustrates the variance inflation factor (VIF) test results for multicollinearity detection (Table 4 in the Appendix) and the estimation outputs of considered function, following several econometric scenarios (models 1-7), as Table 5, in the Appendix, illustrates.

\section{Results}

The VIF tests for multicollinearity detection (Table 4, in the Appendix) demonstrate that, in all cases, the test values are less than 4 . Hence, there is no multicollinearity issue between considered determinants (O’Brien, 2007).

The first outputs reveal that the suggested nonlinear relationship between $\ln$ tax revenues per capita and ln temperature is reinforced by Ramsey's Reset Tests, in the case of naive OLS model 1 (Table 5, in the Appendix). Ramsey's Reset Tests, assuming squares and cubes, confirm the scatter diagram: there is a nonlinear relationship between $\ln$ tax revenues per capita and $\ln$ temperature, leaving a cubic $\cap$ and incomplete $U$-shape, as model 3 (Table 5, in the Appendix) demonstrates. All coefficients of model 3 are significant and also confirm the nonlinear function prediction. The evidence of the polynomial degree 4 is rejected because the F-value of Ramsey's Reset Test is only 1.064, with p-value of 0.31 . Moreover, in this specific case, all coefficients are insignificant (they are not reported in output results). For polynomial degrees greater than 4 , the regressors become perfectly collinear. All these results also reinforce the evidence for the cubic function form.

Employing the control variables, model 4 reports the results of a simple panel OLS model, without the treatment of endogeneity. All interest variables are significant. $\operatorname{Ln} \delta$ and $\delta^{3}$ are positively correlated with $\ln \tau$, while variable $\delta^{2}$ is negative.

The models 5-7 use robust GMM-system estimators with time dummies variables, dealing with the endogeneity issue. The results of model 5 confirm the previous prediction. The first GMM-system estimation employs 30 instruments, the second one 60 , while the third one has 67 instruments.

The Sargan-test and Hansen J-test outputs confirm the null, that all considered instruments are valid (i.e., the instruments are not correlated with the errors in the first-differenced equation). The results for $\operatorname{AR}(2)$ processes in first differences do not find any evidence of autocorrelations.

For all GMM-system estimations, the most important output shows that the interest variables are significant. If $\ln \delta$ and $\delta^{3}$ are positive with respect to dependent variable, and the variable $\delta^{2}$ is negative. These results also confirm the previous nonlinear cubic prediction.

In the case of complete GMM-system model 7, between the control variables, ln GDP, the size of the agricultural sector, the balance of trade, government final consumption expenditures, net FDI, ln freedom of corruption and the literacy index are significant. These regressors are positively correlated with the dependent variables, while the size of the agricultural sector is negative. The rest of the determinants (i.e., the size of the industrial sector, the inflation rate and government debt) are not significant. All these results fully confirm the expected signs established according to the literature.

The signs of the interest variables in model 7 reinforce the evidence of a cubic relationship between tax revenues per capita and temperature, under control of a specific set of variables. The tax revenues cubic function in respect to $\delta$ has a particular incomplete tendency, as Figure 3, in the Appendix, illustrates. 
The tax cubic function with respect to $\delta$ has an oscillating trend, with two critical points: one maximum $\left(\tau_{\max }\right)$ and the other minimum $\left(\tau_{\text {min }}\right)$. $\tau_{1 \mathrm{a}}$ and $\tau_{\mathrm{lb}}$ are the roots of the first derivative cubic function, while $\tau_{2}$ is the root of the second derivative of the same function.

Considering the definition interval of the function $[27.86,86.85]$, the tax revenues cubic function with respect to $\delta$ increases to $\tau_{1 \mathrm{a}}$, decreases between two critical points $\left(\tau_{1 \mathrm{a}}, \tau_{1 b}\right)$, and increases from $\tau_{1 b}$, but only in a very short interval. There is an inflection point $\tau_{\text {inf. }}$ in which the accelerated decreasing trend slows.

In conclusion, the empirical findings in the case of 123 investigated countries for the period 1996-2010 reveal that the relationship between tax revenues per capita and temperature is cubic, with inverted- $U$ and incomplete $U$ shapes. The results reveal that low tax revenues are associated with very low temperatures (cold climates) and that tax revenues tend to increase as temperatures increase, until reaching a maximum (i.e., 43.4 degrees Fahrenheit / 6.33 degrees Celcius, representing the root of the $1^{\text {st }}$ derivative of cubic function, given the coefficients of the interest variables in model 7). After that, even if the temperature increases, tax revenues decrease and reach a low level. In this point, the tax revenue is minimal under a quasi-high temperature (i.e., 72.3 degrees Fahrenheit / 22.38 degrees Celsius, denoting the $2^{\text {nd }}$ root of the first derivative of the considered cubic function). Regarding the next interval, taxes tend to exhibit an ascending incomplete trend under very high temperature (i.e., more than 72.3 degrees Fahrenheit /22.38 degrees Celsius). One may argue that this incomplete tendency is because a very high temperature represents the upper limit of human existence.

\section{Conclusions}

Tax revenues represent the main financial resources of governments. These revenues have several determinants (e.g., economic, socio-demographic and political types). As the economic literature does not take into account geographical conditions concerning tax revenues, our exploration demonstrates this new evidence, using the temperature as the main climate determinant.

The main conclusion states that climate has a significant impact on tax revenues. We also find that governments situated in temperate climate zones, with low to moderate temperatures (the 'optimal temperature' in our investigation), can ensure a good collection of tax revenues. To be able to determine the climate type, we follow Peel, Finlayson and McMahon (2007)'s main contribution, which states that the temperate climate zone is characterized by a temperature with an average level of 0 to 10 degrees Celsius, during the coldest month of the year.

The study suggests that a significant increase of collected tax revenues, without a major negative reaction of taxpayers, can be easily obtained by a public authority situated in temperate climate zones, with low to moderate temperatures. Overall, these climate zones represent 'the best environment for tax revenues', accelerating tax revenue collection.

In the context of tax-policy implications, as there are cyclical climate changes, this contribution can help governments to adjust their tax policy taking into account this climate periodicity. Moreover, governments could better control tax collection based on country climate map positions.

\section{References}

Agbeyegbe, T., Stotsky, J., \& WoldeMariam A. (2006). Trade liberalization, exchange rate changes, and tax revenue in Sub-Saharan Africa. Journal of Asian Economics, 17 (2), 261-284.

Acemoglu, D., Johnson, S., \& Robinson, J. A. (2002). Reversal of Fortune: Geography and Institutions in the Making of the Modern World Income Distribution. Quarterly Journal of Economics, 117 (4), 1231-1294.

Anderson, C. (2001). Heat and violence. Current directions in psychological science, 10 (1), 33-38.

Arellano, M., \& Bond, S. (1991). Some tests of specification for panel data: Monte Carlo evidence and an application to employment equations. The Review of Economic Studies, 58 (2), 277-297.

Bansal, R., \& Ochoa, M. (2012). Temperature, Aggregate Risk, and Expected Returns (Working Paper No. 17575). National Bureau of Economic Research.

Battaglini, M., \& Coate, S. (2008). A Dynamic Theory of Public Spending, Taxation, and Debt. American Economic Review, 98 (1), 201-236.

Berkowitz, L. (1993). Aggression: Its causes, consequences, and control. New York, NY: McGraw Hill.

Bloom, D., \& Sachs, J. (1998), Geography, Demography, and Economic Growth in Africa. Brookings Papers on Economic Activity, 29(2), 207-296. 
Blundell, R., \& Bond, S. (1998). Initial conditions and moment restrictions in dynamic panel data models. Journal of Econometrics, 87 (1), 115-143.

Boyanowsky, E. (1999). Violence and Aggression in the Heat of Passion and in Cold Blood: The EcsTC Syndrome, 22 (3-4), 257-271.

Dell, M., Jones, B., \& Olken, B. (2012). Temperature Shocks and Economic Growth: Evidence from the Last Half Century. American Economic Journal: Macroeconomics, 4 (3), 66-95.

Estrada, F., Mutascu, M., \& Tiwari, A. (2013). Estabilidad política y tributación [Political stability and taxation]. Análisis Político, 77, 133-152.

Fjeldstad, O. H., \& Tungodden, B. (2003). Fiscal Corruption: A vice or a virtue? World Development, 31 (8), 1459-1467.

Friedman, E., Johnson, S., Kaufmann, D., \& Zoido-Lobaton, P. (2000). Dodging the Grabbing Hand: The Determinants of Unofficial Activity in 69 Countries. Journal of Public Economics, 76 (3), 459-493.

Gallup, J., Sachs, J., \& Mellinger, A. (1999). Geography and Economic Development. International Regional Science Review, 22 (2), 179-232.

Gallup, J., \& Sachs, J. (1999). Agricultural Productivity and Geography, [Mimeo], Center for International Development, Cambridge.

Ghura, D. (1998). Tax Revenue in Sub-Saharan Africa: Effects of Economic Policies and Corruption (Working paper No. 98/135). International Monetary Fund.

Hall, R. E., \& Jones, C. I. (1999). Why Do Some Countries Produce So Much More Output Per Worker Than Others? The Quarterly Journal of Economics, 114 (1), 83-116.

Huizinga, H., \& Nicodème, G. (2006). Foreign ownership and corporate income taxation: An empirical evaluation. European Economic Review, 50 (5), 1223-1244.

Huizinga, H., \& Nielsen, S. B. (1997). Capital income and profit taxation with foreign ownership of firms. Journal of International Economics, 42 (1-2), 149-165.

Huizinga, H., \& Nielsen, S.B. (2002). The coordination of capital income and profit taxation with crossownership of firms. Regional Science and Urban Economics, 32 (1), 1-26.

Imam, P., \& Jacobs, D. (2007). Effect of Corruption on Tax Revenues in the Middle East (Working paper No. 07/270). International Monetary Fund.
Katircioglu, S. (2010). Is There a Long-Run Relationship Between Taxation and Growth: The Case of Turkey. Romanian Journal of Economic Forecasting, 13 (1), 99-106.

Kenny, L. W., \& Winer, S. L. (2006). Tax Systems in the World: An Empirical Investigation into the Importance of Tax Bases, Administration Costs, Scale and Political Regime. International Tax and Public Finance, 13 (2-3), 181-215.

Lago-Peñas, I., \& Lago-Peñas, S. (2008). The Determinants of Tax Morale in Comparative Perspective: Evidence from a Multilevel Analysis (Working Paper No. 2/2008). The Institute for Fiscal Studies.

Mahdavi, S. (2008). The level and composition of tax revenue in developing countries: evidence from unbalanced panel data. International Review of Economics and Finance, 17 (4), 607-617.

Marshall, M., Gurr, T. R., \& Jaggers, K. (2011). Political Regime Characteristics and Transitions, 18002010. Dataset Users' Manual. Center for Systemic Peace. Available, at http://www.systemicpeace. org/inscr/p4manualv2013.pdf

McDougall, W. (2005). The Group Mind: A Sketch of the Principles of Collective Psychology with Some Attempt to Apply Them to the Interpretation of National Life and Character. Whitefish, MT: Kessinger Publishing, LLC.

Mintz, J. M. (1994). Is there a future for capital income taxation? Canadian Tax Journal, 42 (6), 1469-1503.

Mellinger, A., Sachs, J., \& Gallup, J. (1999). Climate, Water Navigability, and Economic Development, (Working Paper No. 24). Center for International Development at Harvard University.

Montesquieu, C. (1989). The Spirit of Laws In A. Cohler, B. C. Miller, \& H. S. Stone (Eds.), Cambridge Texts in the History of Political Thought, Edinburgh, Cambridge University Press. (Original work published 1750)

Nordhaus, W. D. (2006). Geography and macroeconomics: New data and new findings. PNAS, 103 (10), 3510-3517.

O'Brien, R. (2007). A Caution Regarding Rules of Thumb for Variance Inflation Factors. Quality \& Quantity, 41 (5), 673-690.

Olivera, J. (1967). Money, prices and fiscal lags. A note on the dynamics of inflation. Banca Nazionale del Lavoro Quaterly Review, 20, 258-267. 
Peel, M., Finlayson, B., \& McMahon, T. (2007). Updated world map of the Köppen-Geiger climate classification. Hydrology and Earth System Sciences, 11 (5), 1633-1644.

Rehdanz, K., \& Maddison, D. (2005). Climate and happiness. Ecological Economics, 52 (1), 111-125.

Richter, W. F., \& Wellisch, D. (1996). The provision of local public goods and factors in the presence of firm and household mobility. Journal of Public Economics, 60 (1), 73-93.

Roodman, D. (2009a). How to Do Xtabond2: An Introduction to Difference and System GMM in Stata. The Stata Journal, 9 (1), 86-136.

Roodman, D. (2009b). A Note on the Theme of Too Many Instruments. Oxford Bulletin of Economics and Statistics, 71 (1), 135-158.

Rodrik, D., Subramanian, A., \& Trebbi, F. (2004). Institutions Rule: The Primacy of Institutions Over Geography and Integration in Economic Development. Journal of Economic Growth, 9 (2), 131-165.

Sachs, J. D, \& Warner, A.M. (1997). Sources of Slow Growth in African Economies. Journal of African Economies, 6 (3), 335-376.

Sylwester, K. (2004). A note on geography, institutions, and income inequality. Economics Letters, 85 (2), 235-240.

Smith, A. (1776), An Inquiry into the Nature and Causes of the Wealth of Nations. (Vols. 2) E. Canaan (Ed)., Chicago, IL: University of Chicago Press.

Taha, R., \& Loganathan, N. (2008). Causality Between Tax Revenue and Government Spending in Malaysia. The International Journal of Business and Finance Research, 2(2), 63-73.

Tanzi, V. (1977). Inflation, lags in collection and the real value of the tax revenue. Staff Papers - International Monetary Fund, 24 (1), 154-167.

Tosun, M. S., \& Abizadeh S. (2005). Economic growth and tax components: An analysis of tax changes in OECD. Applied Economics, 37 (19), 2251-2263.

Wildasin, D. (2003). Fiscal competition in space and time. Journal of Public Economics, 87 (11), 2571-2588.

Wildasin, D., \& Wilson, J. D. (1998). Risky local bases: Risk-pooling vs. rent-capture. Journal of Public Economics, 69 (2), 229-247.

$* * *$ (2012). The Heritage Foundation online database.

*** (2011). International Panel on Climate Change, www.ipcc.ch.
*** (2011). International Monetary Fund online database.

*** (2011). Polity ${ }^{\mathrm{m}}$ IV Project Political Regime Characteristics and Transitions, 1800-2010 Dataset.

*** (2011). UK Met Office Online database 2012.

*** (2011). United Nations Development Programme online database.

*** (2011). World Bank online database. 


\section{Appendix}

Table 1. List of analyzed countries

\begin{tabular}{|c|c|c|c|c|c|}
\hline \multicolumn{6}{|c|}{ Countries } \\
\hline Albania & Central African Rep. & Germany & Lao People's Dem. Rep & Niger & Swaziland \\
\hline Algeria & Chad & Ghana & Latvia & Nigeria & Sweden \\
\hline Argentina & Chile & Greece & Lebanon & Norway & Switzerland \\
\hline Armenia & China, P.R.: Mainland & Guatemala & Lesotho & Oman & Tajikistan \\
\hline Australia & Colombia & Guyana & Libya & Pakistan & Togo \\
\hline Austria & Costa Rica & Honduras & Lithuania & Panama & Trinidad and Tobago \\
\hline Azerbaijan, Rep. of & Croatia & Hungary & Macedonia, FYR & Paraguay & Tunisia \\
\hline Bahrain, Kingdom of & Cyprus & India & Madagascar & Peru & Turkey \\
\hline Bangladesh & Czech Republic & Indonesia & Malawi & Philippines & Uganda \\
\hline Belarus & Denmark & Iran, I.R. of & Malaysia & Poland & Ukraine \\
\hline Belgium & Djibouti & Ireland & Mali & Portugal & United Arab Emirates \\
\hline Benin & Dominican Republic & Israel & Mauritius & Qatar & United Kingdom \\
\hline Bolivia & Ecuador & Italy & Mexico & Romania & United States \\
\hline Botswana & Egypt & Jamaica & Moldova & Russian Federation & Uruguay \\
\hline Brazil & El Salvador & Japan & Mongolia & Rwanda & Uzbekistan \\
\hline Bulgaria & Estonia & Jordan & Morocco & Saudi Arabia & Venezuela, Rep. Bol. \\
\hline Burkina Faso & Ethiopia & Kazakhstan & Mozambique & Senegal & Vietnam \\
\hline Burundi & Fiji & Kenya & Nepal & Slovak Republic & Zambia \\
\hline Cambodia & Finland & Korea, Republic of & Netherlands & Slovenia & \\
\hline Cameroon & France & Kuwait & New Zealand & Spain & \\
\hline Canada & Georgia & Kyrgyz Republic & Nicaragua & Sudan & \\
\hline
\end{tabular}


Table 2. Descriptive statistics

\begin{tabular}{|c|c|c|c|c|c|c|}
\hline Variable & Mean & Median & Maximum & Minimum & Std. Dev. & Observations \\
\hline $\begin{array}{c}\text { Tax revenues per capita } \\
\text { (US dollars) }\end{array}$ & 4086.996 & 1017.771 & 54524.7 & 16.65197 & 6706.182 & 1187 \\
\hline Temperature (oF) & 64.32737 & 64.96961 & 86.855 & 27.86 & 14.16238 & 1187 \\
\hline GDP (Millions dollars) & 386061 & 48187.63 & 14465108 & 624.97 & 1264221 & 1187 \\
\hline $\begin{array}{c}\text { Size of industrial sector as } \\
\% \text { of GDP }\end{array}$ & 0.310861 & 0.29142 & 0.785181 & 0.105153 & 0.104158 & 1187 \\
\hline $\begin{array}{c}\text { Size of agricultural sector } \\
\text { as } \% \text { of GDP }\end{array}$ & 0.127194 & 0.076197 & 0.597204 & 0.003552 & 0.124553 & 1187 \\
\hline Inflation rate as \% of GDP & 0.064641 & 0.041727 & 1.328238 & -0.09863 & 0.084418 & 1187 \\
\hline $\begin{array}{c}\text { Balance of trade as \% } \\
\text { of GDP }\end{array}$ & -0.03476 & -0.02434 & 0.458385 & -1.00971 & 0.12361 & 1187 \\
\hline $\begin{array}{l}\text { General government } \\
\text { gross debt as \% of GDP } \\
\text { Government final }\end{array}$ & 0.529043 & 0.457 & 2.6183 & 0.0055 & 0.350767 & 1187 \\
\hline $\begin{array}{c}\text { consumption } \\
\text { expenditure as \% of GDP }\end{array}$ & 0.155827 & 0.156669 & 0.305042 & 0.026753 & 0.052205 & 1187 \\
\hline $\begin{array}{l}\text { Net FDI as percent of } \\
\text { GDP }\end{array}$ & 0.025454 & 0.019481 & 0.465006 & -0.2279 & 0.046266 & 1187 \\
\hline Freedom from corruption & 43.38416 & 35 & 100 & 10 & 23.05044 & 1187 \\
\hline Literacy index & 0.860864 & 0.940687 & 1 & 0.080294 & 0.193943 & 1187 \\
\hline Regime durability & 27.52401 & 15 & 200 & 0 & 32.61493 & 1187 \\
\hline
\end{tabular}

Table 3. Source of data

\begin{tabular}{|c|c|}
\hline Variable & Source \\
\hline Tax revenues per capita (US dollars) & International Monetary Fund online database (2011). \\
\hline Temperature (oF) & UK Met Office Online database 2012. \\
\hline GDP (Millions US dollars) & $\begin{array}{l}\text { United Nations Conference on Trade and Development } \\
\text { (UNCTAD) online database (2011). }\end{array}$ \\
\hline Size of industrial sector as \% of GDP & World Bank online database (2011). \\
\hline Size of agricultural sector as \% of GDP & World Bank online database (2011). \\
\hline Inflation rate as \% per annum & International Monetary Fund online database (2011). \\
\hline Balance of trade as \% of GDP & International Monetary Fund online database (2011). \\
\hline General government gross debt as \% of GDP & International Monetary Fund online database (2011). \\
\hline Government final consumption expenditure as \% of GDP & World Bank online database (2011). \\
\hline Net FDI & United Nations Development Programme online database (2011). \\
\hline Freedom from corruption & The Heritage Foundation online database (2012). \\
\hline Literacy index & United Nations Development Programme online database (2011). \\
\hline Regime durability & $\begin{array}{l}\text { Polity }^{\mathrm{TM}} \text { IV Project Political Regime Characteristics and } \\
\text { Transitions, 1800-2010 Dataset (2011). }\end{array}$ \\
\hline
\end{tabular}


Table 4. Variance inflation factor test results for climate dummy and temperature models

\begin{tabular}{ccc}
\hline Variables/tests & VIF & 1/VIF \\
\hline size of agricultural as \% of GDP & 4.05 & 0.247145 \\
balance of trade as \% of GDP & 2.59 & 0.385561 \\
In GDP & 2.41 & 0.414283 \\
size of industrial as \% of GDP & 2.41 & 0.415257 \\
In freedom of corruption & 2.21 & 0.451908 \\
literacy index & 2.19 & 0.456344 \\
government final consumption expenditure as \% of GDP & 1.7 & 0.587849 \\
In temperature & 1.61 & 0.622004 \\
regime durability & 1.51 & 0.660168 \\
net FDl as \% in GDP & 1.51 & 0.661974 \\
inflation rate (\%) & 1.28 & 0.779576 \\
Menen VIF & 1.17 & 0.858316 \\
\hline
\end{tabular}

Table 5. Empirical results of panel regressions

\begin{tabular}{|c|c|c|c|c|c|c|c|c|}
\hline \multirow{2}{*}{$\begin{array}{l}\text { Independent } \\
\text { variables }\end{array}$} & \multicolumn{7}{|c|}{ Model } & \multirow{2}{*}{$\begin{array}{l}\text { Expected } \\
\text { sign }\end{array}$} \\
\hline & (1) & (2) & (3) & (4) & (5) & (6) & (7) & \\
\hline constant & $\begin{array}{c}20.424^{* * *} \\
(0.776)\end{array}$ & $\begin{array}{c}-86.638^{* * *} \\
(10.877)\end{array}$ & $\begin{array}{l}-717.57^{* * *} \\
(137.286)\end{array}$ & $\begin{array}{c}-237.505^{* *} \\
(63.111)\end{array}$ & & & & \\
\hline In temperature & $\begin{array}{c}-3.276^{* * *} \\
(0.186)\end{array}$ & $\begin{array}{l}49.735^{* * *} \\
(5.376)\end{array}$ & $\begin{array}{l}529.561^{* * *} \\
(104.219)\end{array}$ & $\begin{array}{c}177.319^{* * *} \\
(47.637)\end{array}$ & $\begin{array}{l}1344.01^{* * *} \\
(506.518)\end{array}$ & $\begin{array}{l}1055.512^{* * *} \\
(275.901)\end{array}$ & $\begin{array}{l}482.448^{* *} \\
(220.891)\end{array}$ & + \\
\hline In temperature ${ }^{2}$ & & $\begin{array}{c}-6.533^{* * *} \\
(0.662)\end{array}$ & $\begin{array}{c}-127.731^{* * *} \\
(26.298)\end{array}$ & $\begin{array}{c}-43.612^{* * *} \\
(11.954)\end{array}$ & $\begin{array}{l}-336.437^{* *} \\
(131.152)\end{array}$ & $\begin{array}{c}-266.052^{* * *} \\
(70.661)\end{array}$ & $\begin{array}{c}-120.321^{* *} \\
(56.028)\end{array}$ & - \\
\hline In temperature ${ }^{3}$ & & & $\begin{array}{c}10.168^{* * *} \\
(2.205)\end{array}$ & $\begin{array}{c}3.553^{* * *} \\
(0.997)\end{array}$ & $\begin{array}{l}27.956^{* *} \\
(11.274)\end{array}$ & $\begin{array}{c}22.259^{* * *} \\
(6.019)\end{array}$ & $\begin{array}{l}9.962^{* *} \\
(4.728)\end{array}$ & + \\
\hline In GDP & & & & $\begin{array}{l}0.171^{* * *} \\
(0.013)\end{array}$ & $\begin{array}{c}0.591^{* * *} \\
(0.217)\end{array}$ & $\begin{array}{c}0.327^{* * *} \\
(0.058)\end{array}$ & $\begin{array}{c}0.264^{* * *} \\
(0.054)\end{array}$ & + \\
\hline $\begin{array}{c}\text { size of industrial sector } \\
\text { as } \% \text { of GDP }\end{array}$ & & & & $\begin{array}{l}-0.462^{*} \\
(0.258)\end{array}$ & $\begin{array}{l}-0.908 \\
(0.625)\end{array}$ & $\begin{array}{l}-1.409 \\
(0.897)\end{array}$ & $\begin{array}{l}-0.917 \\
(0.757)\end{array}$ & + \\
\hline $\begin{array}{l}\text { size of agricultural } \\
\text { sector as \% of GDP }\end{array}$ & & & & $\begin{array}{l}-5.294^{* * *} \\
(0.282)\end{array}$ & $\begin{array}{l}-5.241 * * \\
(2.281)\end{array}$ & $\begin{array}{l}-7.932^{* * *} \\
(0.866)\end{array}$ & $\begin{array}{c}-4.901^{* * *} \\
(0.786)\end{array}$ & - \\
\hline inflation rate (\%) & & & & $\begin{array}{c}-1.129^{* * *} \\
(0.222)\end{array}$ & & $\begin{array}{l}-0.493 \\
(0.909)\end{array}$ & $\begin{array}{l}0.415 \\
(0.834)\end{array}$ & - \\
\hline $\begin{array}{c}\text { balance of trade as \% } \\
\text { of GDP }\end{array}$ & & & & $\begin{array}{c}1.086^{* * *} \\
(0.227)\end{array}$ & & $\begin{array}{c}1.389 \\
(0.914)\end{array}$ & $\begin{array}{l}1.546^{* *} \\
(0.772)\end{array}$ & + \\
\hline $\begin{array}{l}\text { general government } \\
\text { gross debt as \% of GDP }\end{array}$ & & & & $\begin{array}{l}0.136^{* *} \\
(0.056)\end{array}$ & & $\begin{array}{c}0.423 \\
(0.323)\end{array}$ & $\begin{array}{c}0.018 \\
(0.263)\end{array}$ & + \\
\hline
\end{tabular}


Table 5. Continued

\begin{tabular}{|c|c|c|c|c|c|c|c|c|}
\hline \multirow{2}{*}{$\begin{array}{l}\text { Independent } \\
\text { variables }\end{array}$} & \multicolumn{7}{|c|}{ Model } & \multirow{2}{*}{$\begin{array}{l}\text { Expected } \\
\text { sign }\end{array}$} \\
\hline & (1) & (2) & (3) & (4) & (5) & (6) & (7) & \\
\hline \multicolumn{9}{|l|}{ government final } \\
\hline $\begin{array}{c}\text { consumption } \\
\text { expenditure as \% of } \\
\text { GDP }\end{array}$ & & & & $\begin{array}{l}4.770^{* * *} \\
(0.454)\end{array}$ & & $\begin{array}{l}4.693^{*} \\
(2.767)\end{array}$ & $\begin{array}{l}5.582^{* *} \\
(2.271)\end{array}$ & + \\
\hline net FDI as $\%$ in GDP & & & & $\begin{array}{l}-0.144 \\
(0.461)\end{array}$ & & $\begin{array}{l}2.699 \\
(3.043)\end{array}$ & $\begin{array}{l}4.274^{*} \\
(2.566)\end{array}$ & + \\
\hline $\begin{array}{l}\text { In freedom of } \\
\text { corruption }\end{array}$ & & & & $\begin{array}{c}0.707^{* * *} \\
(0.046)\end{array}$ & & & $\begin{array}{c}0.742^{* * *} \\
(0.107)\end{array}$ & + \\
\hline literacy index & & & & $\begin{array}{c}1.428^{* * *} \\
(0.135)\end{array}$ & & & $\begin{array}{c}1.095^{* * *} \\
(0.269)\end{array}$ & + \\
\hline regime durability & & & & $\begin{array}{l}0.004^{* * *} \\
(0.0006)\end{array}$ & & & $\begin{array}{l}0.004^{* *} \\
(0.001)\end{array}$ & $+/-$ \\
\hline $\begin{array}{c}\text { In tax revenues per } \\
\text { capita (t-1) }\end{array}$ & & & & & $\begin{array}{l}-0.058 \\
(0.145)\end{array}$ & $\begin{array}{l}-0.021 \\
(0.071)\end{array}$ & $\begin{array}{l}-0.015 \\
(0.059)\end{array}$ & \\
\hline Time dummies & & & & & Yes & Yes & Yes & \\
\hline Type of estimation & PLS naive & PLS naive & PLS naive & PLS & $\begin{array}{c}\text { GMM } \\
\text { system }\end{array}$ & $\begin{array}{c}\text { GMM } \\
\text { system }\end{array}$ & $\begin{array}{c}\text { GMM } \\
\text { system }\end{array}$ & \\
\hline \multicolumn{9}{|c|}{ Model summary } \\
\hline R-squared & 0.173 & 0.224 & 0.235 & 0.900 & & & & \\
\hline $\begin{array}{l}\text { RESET-test (cube) } \\
\text { RESET-test (squares) }\end{array}$ & $\begin{array}{c}F=101.419 \\
\text { with } \\
p \text {-value = } \\
4.07 e-023 \\
F=97.338, \\
\text { with } \\
\text { p-value = } \\
\text { 2.8e-022 }\end{array}$ & & & & & & & \\
\hline $\begin{array}{l}\operatorname{Ar}(1) \\
\operatorname{Ar}(2)\end{array}$ & & & & & $\begin{array}{c}z=-2.74 \\
\operatorname{Pr}>z=0.006 \\
z=0.21 \\
\operatorname{Pr}>z=0.835\end{array}$ & $\begin{array}{c}z=-4.61 \\
\operatorname{Pr}>z=0.000 \\
z=-1.30 \\
\operatorname{Pr}>z=0.193\end{array}$ & $\begin{array}{c}z=-4.75 \\
\operatorname{Pr}>z=0.000 \\
z=-1.47 \\
\operatorname{Pr}>z=0.142\end{array}$ & \\
\hline Number of instruments & & & & & 30 & 67 & 70 & \\
\hline Sargan probability & & & & & 0.384 & 0.563 & 0.522 & \\
\hline $\begin{array}{c}\text { Hansen J-test } \\
\text { probability }\end{array}$ & & & & & 0.538 & 0.503 & 0.394 & \\
\hline
\end{tabular}

Notes:(a) (...) denotes the standard error. (b) PLS represents panel least squares. (c) GMM denotes generalized method of moments. (d) ${ }^{* *},{ }^{* *}$, and ${ }^{*}$ denote significance at 1,5 and $10 \%$ level of significance, respectively. 


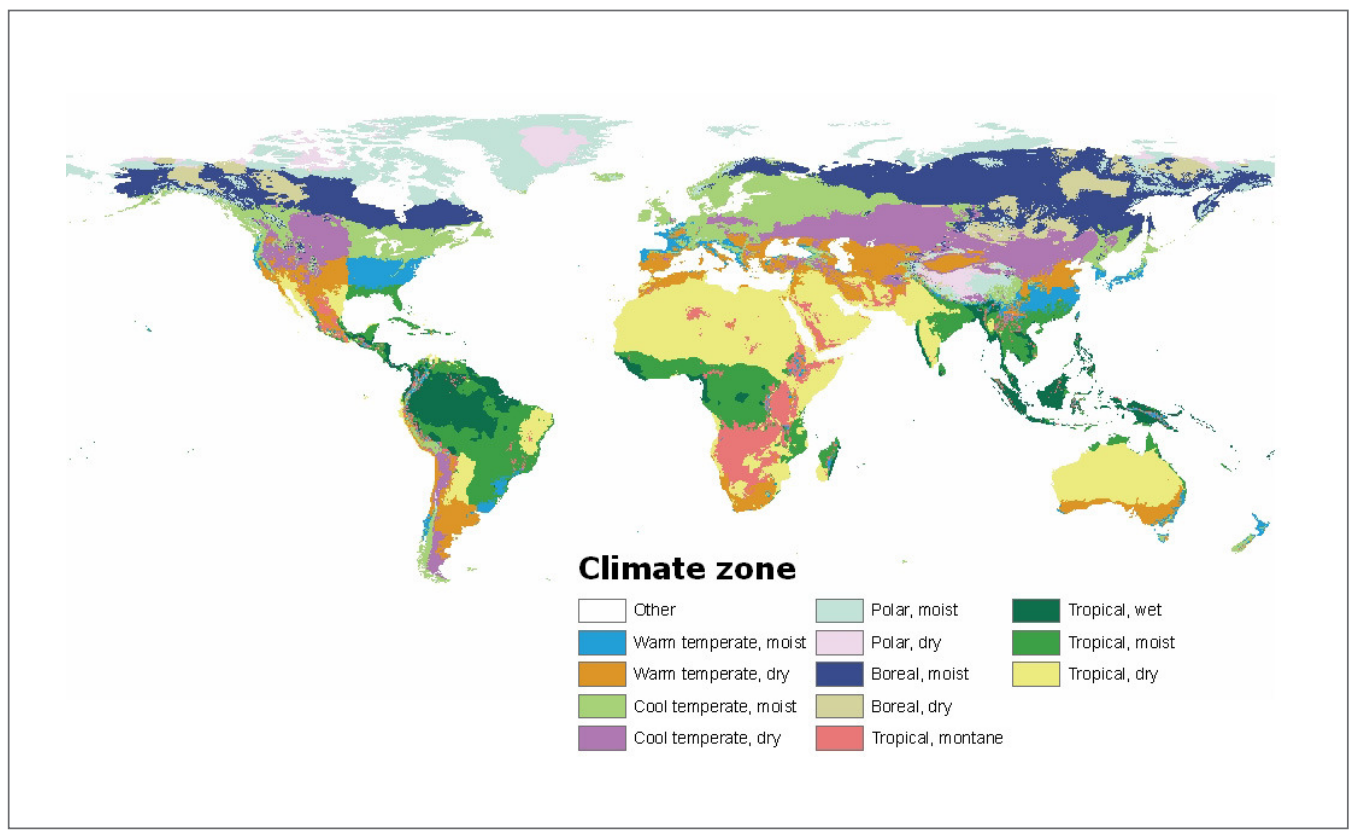

Figure 2. Climate zone types. Source: International Panel on Climate Change (1996), www.ipcc.ch

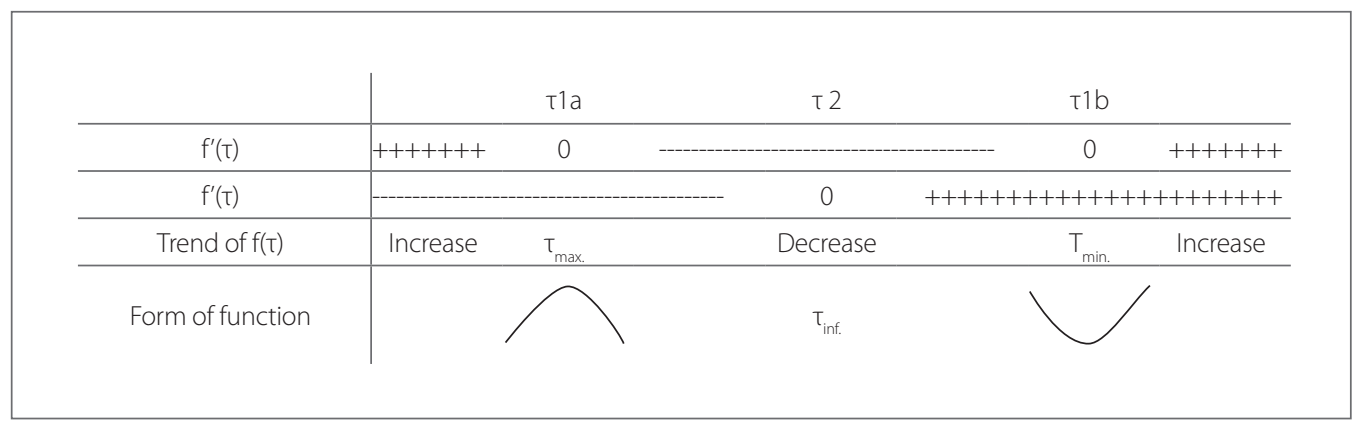

Figure 3. The tendency of cubic tax function with respect to temperature 